DP - 911

\title{
ALUMINUM CORROSION IN SUBCRITICAL AND ZERO POWER CRITICAL REACTORS
}

M. E. BERGSTRESSER

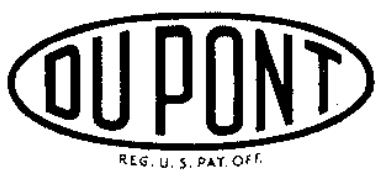

ISSUED BY

Savannah River Laboratory

Aiken, South Carolina 
Th1s report was prepared as an account of Government sponsored work. Nelther the United States, nor the Commission, nor any person acting on behalf of the commission:

A. Makes any warranty or representation, expressed or implied, with respect to the accuracy, completeness, or usefulness. of the information contained in this report, or that the use of any information, apparatus, method, or process dis.closed in this report may not infringe privately owned rights; or

B. Assumes any 11ab1l1t1es with respect to the use of or for damages resulting from the use of any information, apparatus, method, or process disclosed in this report.

As used in the above, "person acting on behalf of the Commission" includes any employee or contractor of the Commission, or employee of such contractor, to the extent that such employee or contractor of the Commission, or employee of such contractor prepares, disseminates, or provides access to, any information pursuant to his employment or contract with the Commission, or his employment with such contractor.

Printed in USA. Price $\$ 0.50$

Avaslable from the office of Technical Services

U. S. Department of Cominerce

Washington 25, D. C. 
Metals, Ceramics, and Materials

(TID-4500, 3lst Ed.)

\title{
ALUMINUM CORROSION IN SUBCRITICAL AND ZERO POWER CRITICAL REACTORS
}

\section{$a$}

by

Mack E. Bergstresser

\author{
Approved by
}

T. C. Evans, Superintendent
Engineering Assistance Section
Works Technical Department
Savannah River Plant

July 1964

\author{
E. I. DU PONT DE NEMOURS \& COMPANY \\ SAVANNAH RIVER LABORATORY \\ AIKEN, SOUTH CAROLINA \\ CONTRACT AT(07.2).1 WITH THE \\ UNITED STATES ATOMIC ENERGY COMMISSION
}




\begin{abstract}
Natural uranium aluminum-clad fuel slugs are subject to corrosion in low temperature $\left(\angle 100^{\circ} \mathrm{C}\right)$ water during service in subcritical and zero power nuclear reactors. This report discusses pitting corrosion and galvanic corrosion of aluminum in such service. The use of high purlty water or the addition of chromates as inhibitors will minimize the corrosion rates.
\end{abstract}




\section{CONTENTS}

Page

Introduction . . . . . . . . . . . . . . . . . I

Summary. . . . . . . . . . . . . . . . . 1

Recommendations. . . . . . . . . . . . I 1

Discussion................. 3

Low Temperature Corroston ............ 3

Methods of Preventing Corrosion . . . . . . 6

B1bliography . . . . . . . . . . . . 8

General References............ . . 8

LIST OF FIGURES

Figure

I Ion Exchange Column ............ . 2

2 Pitting Corrosion Attack on Type 1100

Aluminum . . . . . . . . . . . . . 5

$-111-$ 


\section{ALUMINUM CORROSION IN SUBCRITICAL AND ZERO POWER CRITICAL REACTORS}

\section{INTRODUCTION}

Subcritical and zero power critical reactors are used for nuclear research and instruction by agencies outside the Atomic Energy Commission. Such reactors are fueled with slugs of natural uranium clad with type 1100 aluminum, and are moderated by $\mathrm{H}_{2} \mathrm{O}, \mathrm{D}_{2} \mathrm{O}$, or graphite. In all cases the fuel slugs are immersed in either $\mathrm{H}_{2} \mathrm{O}$ or $\mathrm{D}_{2} \mathrm{O}$ and operate at room temperature. Corrosion of the aluminum cladding material occurs during operation of these reactors. This report describes the types of aluminum corrosion that occur In low temperature water $\left(<100^{\circ} \mathrm{C}\right)$ and recommends methods of preventing such corrosion. The recommendations, which are based on operating experience at the Savannah River Plant, may be useful to those who operate subcritical and zero power critical reactors.

\section{SUMMARY}

Aluminum cladding on slugs, and aluminum reactor components used in small research reactors are subject to pitting and galvanic corrosion while immersed in stagnant $\mathrm{H}_{2} \mathrm{O}$ or $\mathrm{D}_{2} \mathrm{O}$ at low temperatures $\left(<100^{\circ} \mathrm{C}\right)$.

Pitting corrosion is promoted by the presence of chlorlde lons and heavy metal ions such as $\mathrm{Cu}, \mathrm{Cr}$, Hg, and Ag. Removal of such lons from solution prevents pitting.

Galvanic corrosion occurs when dissimilar metals in electrical contact are exposed to an electrolyte. Such couples between aluminum-clad slugs and dissimilar metals should be avolded. Reduction of the conductivity of the electrolyte (by purifying or delonizing the water) reduces the current flow.

\section{RECOMMENDATIONS}

The following procedure is recommended to prevent low temperature corrosion of aluminum in $\mathrm{H}_{2} \mathrm{O}$ or $\mathrm{D}_{2} \mathrm{O}$.

1. Use high purlty water with a conductivity of $0.1-0.2 \mu m h o / \mathrm{cm}$. Water may be purified and maintained pure through the use of an ion exchange resin column such as is shown in Figure 1. 


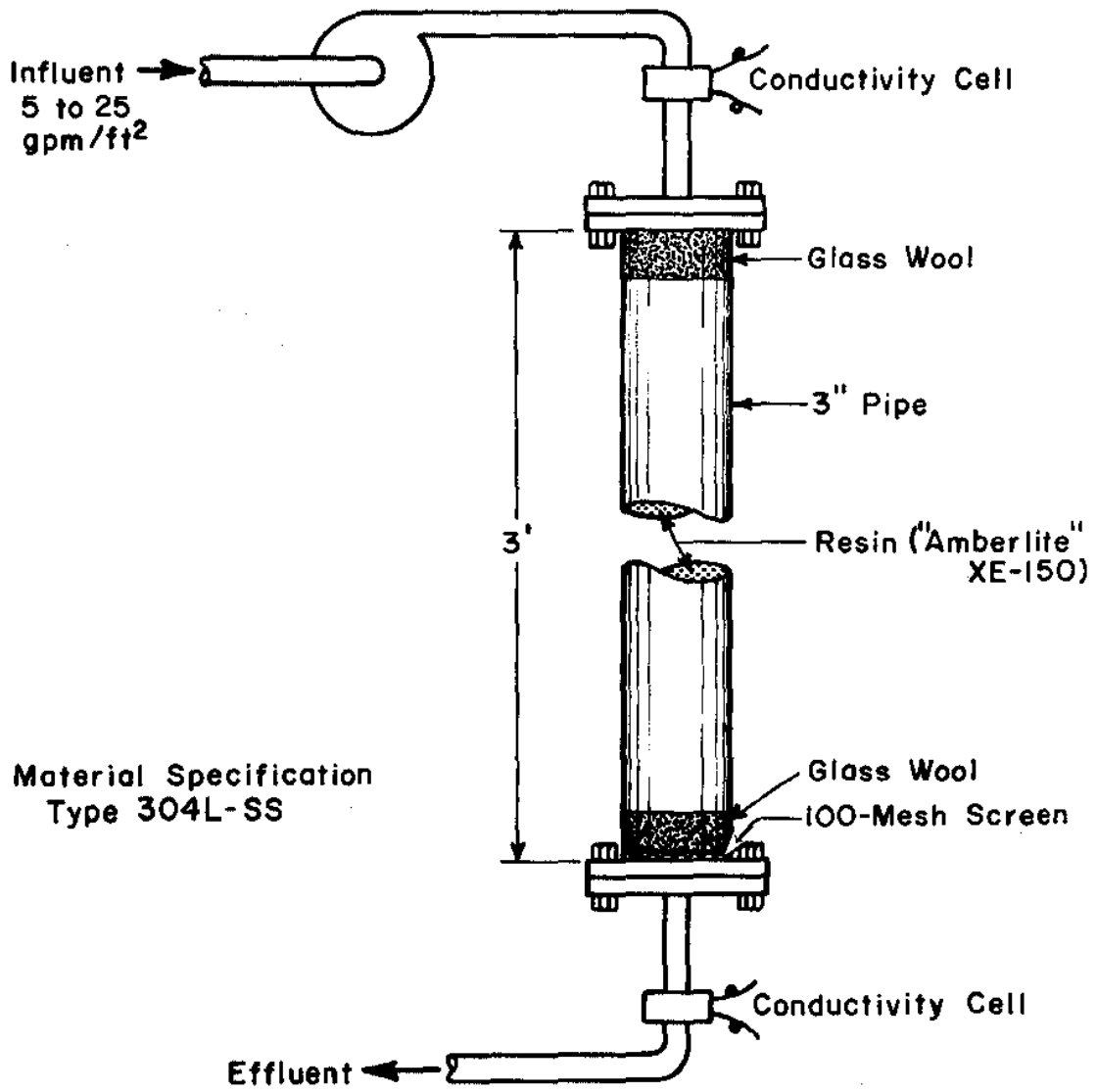

FIG. 1 ION EXCHANGE COLUMN 
As an alternative method for preventing corrosion, $\mathrm{MgCrO}_{4}$ at $0.03 \mathrm{M}$ concentration is preferred. However, $\mathrm{CaCrO}_{4}$ or $\mathrm{Na}_{2} \mathrm{CrO}_{4}-$ $\mathrm{MgCrO}_{4}$ at $0.03 \mathrm{M}$ concentration can be used. (NOTE: Inhibitors and ion exchange resin columns cannot be used in the same system.)

2. Avold couples between aluminum and dissimilar metals.

3. Handle aluminum-clad slugs with utmost care. Do not remove, break, or destroy the protective oxide layer on the aluminum surface.

\section{DISCUSSION}

A protective hydrated oxide layer $\sim 0.0001$ inch thick is formed on the aluminum cladding surface of fuel slugs by steam autoclaving following the fabrication process. This protective oxide $\left(\alpha \mathrm{Al}_{2} \mathrm{O}_{3} \cdot \mathrm{H}_{2} \mathrm{O}\right)$ provides a passive surface that increases the corrosion resistance of aluminum in water.

In service, aluminum cladding and reactor components are subject to four types of corrosion: pitting, galvanic, general, and intergranular. Because there are differences In these corrosion phenomena, "low temperature" corrosion $\left(<100^{\circ} \mathrm{C}\right)$ is distinguished from "high temperature" corrosion $\left(>100^{\circ} \mathrm{C}\right)$. Pitting and galvanic corrosion occur generally in the low temperature range, while general and intergranular corrosion occur in the high temperature range. Other than temperature, the principal factor influencing the corrosion rates of aluminum is the purity of the water.

\section{Low Temperature Corrosion}

\section{Pitting Corrosion}

Small, normally white, crystalline or gelatinous deposits on the surface of aluminum are evidence of pltting corrosion. P1tting (1,2) begins by breakdown of passivity at a favored nucleus. This breakdown is followed by the formation of an electrolytic cell where the exposed metal at the minute area under the broken $f 1 \mathrm{~lm}$ is anodic, resulting In a rapid corrosion rate.

The reactions for the general corrosion of aluminum in $\mathrm{H}_{2} \mathrm{O}$ or $\mathrm{D}_{2} \mathrm{O}$ where $\mathrm{AI}^{+3}$ is the dominant ion can be expressed as follows: 


$$
\begin{aligned}
& 2 A I=2 A I^{+3}+6 e^{-} \quad \text { Anodic reaction } \\
& 6 \mathrm{e}^{-}+6 \mathrm{H}_{2} \mathrm{O}=3 \mathrm{H}_{2}+6 \mathrm{OH}^{-} \quad \text { Cathodic reaction } \\
& 2 \mathrm{Al}^{+3}+6 \mathrm{OH}^{-}=2 \mathrm{Al}(\mathrm{OH})_{3}(\beta \text {-trinydrate }) \text { Precipltation reaction } \\
& 2 \mathrm{Al}+6 \mathrm{H}_{2} \mathrm{O}=2 \mathrm{AI}(\mathrm{OH})_{3}+3 \mathrm{H}_{2} \quad \text { Over-all reaction }
\end{aligned}
$$

The concentration of aluminum ions in the solution adfacent to the point of fallure soon exceeds the solubility of the aluminum hydroxide and a precipitate is formed $(1,2)$. Inftialiy, the precipitate is gelatinous (Figure 2), which hinders the migration of the aluminum ions from the surface and causes a crystaline deposit to form around the point of attack. The reactions of the aluminum ions, impurity ions, and hydroxyl lons from the water form soluble complexes to produce acidity at the point where no film exists. The acidity prevents formation of a passive oxide film in this area and results in little or no resistance to corrosion of the metal under the deposit. The rate of corrosion is then governed by the cathodic reaction; therefore, the factors Inltiating the pit formation are no longer essential for its growth.

Pitting corrosion is strongly inltiated by chlorides and the lons of heavy metals such as $\mathrm{Cu}, \mathrm{Cr}$, $\mathrm{Hg}$, and $\mathrm{Ag}$. The quant1ty (2) of these ions in the water must be reduced below a critical concentration to prevent pitting, because these metals will deposit electrochemlcally and have potentials that are noble (cathodic) to the potential of the aluminum. The potential on the aluminum surface varies from point to point; at highly anodic points the deposition potential is greatest and a more noble metal is most likely to be deposited.

Reduction of the thickness of the protective layer, or complete removal in localized areas, can result from improper handling of the slugs during charging or discharging operations. Minor breaks in the protective layer produce ldeal locations for pit formation. The utmost care should therefore be used in handling uranium slugs.

\section{Galvanic Corrosion}

Galvanic corrosion of aluminum is related to pitting corrosion; however, it is normally associated with the contact of aluminum and dissimilar metals. When dissimilar metals ${ }^{(3)}$ in electrical contact are exposed to an electrolyte, a galvanic current flows from one to the other; corrosion of the anodic member of the couple is directly related to the galvanic current by Faraday's law.

$$
-4-
$$




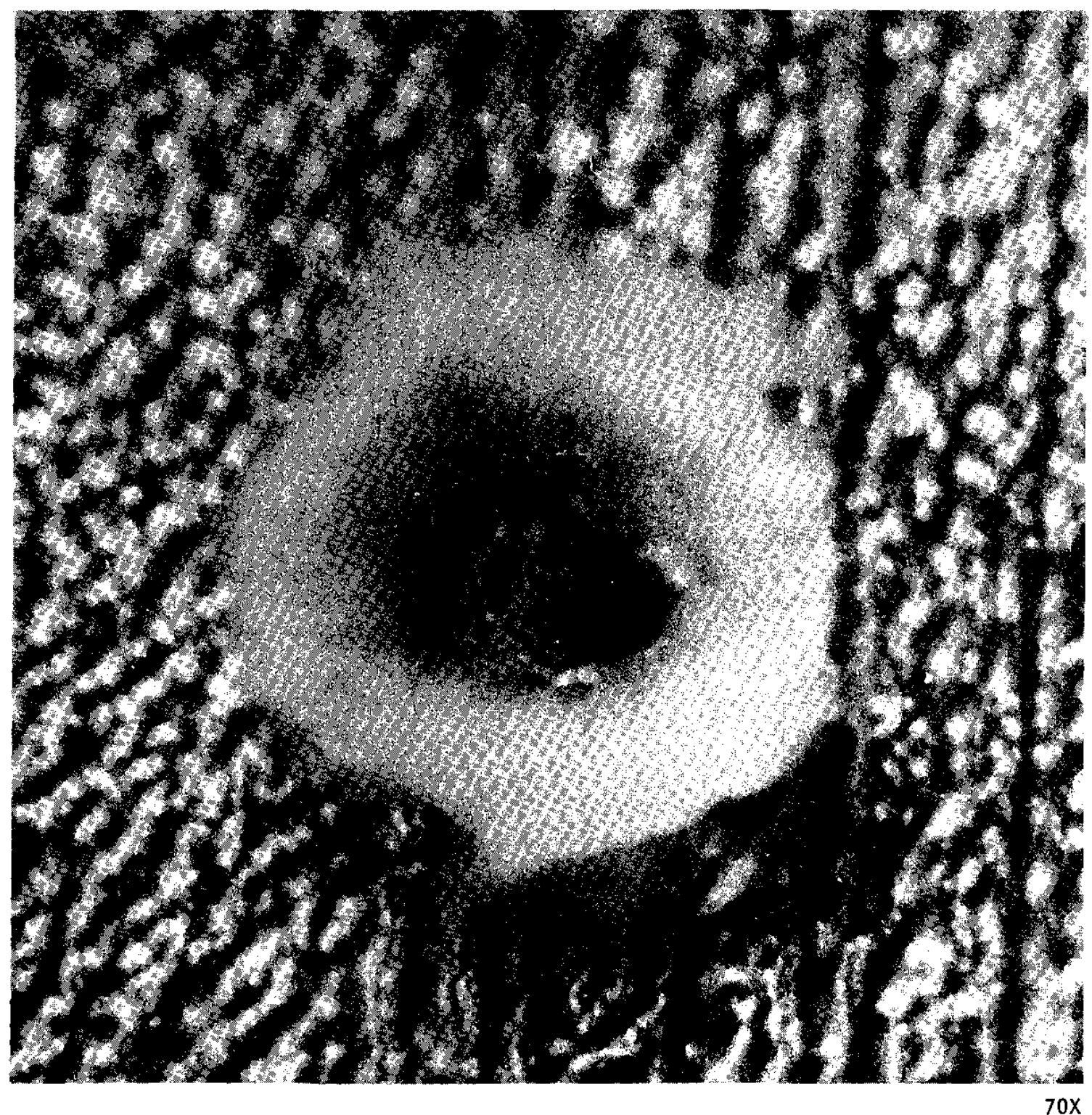

FIG. 2 PITTING CORROSION ATTACK ON TYPE 1100 ALUMINUM The $A I(O H)_{3}$ deposit around the periphery of the pit is in the gelatinous state 
Couples between aluminum-clad slugs and supports of dissimilar metals should be avolded. In addition, reduction of the conductivity of the electrolyte will reduce the current flow.

\section{Corrosion Medium}

Tests (1) have shown that no pltting corrosion w1ll occur on aluminum, even when in contact with stalniess steel, as long as the water is sufflclently pure. Water becomes more corrosive to aluminum with increasing content of corrosion products. Fallure to remove or prevent the formation of corrosion products eventually makes the water so corrosive that pitting develops.

The $\mathrm{H}_{2} \mathrm{O}$ and $\mathrm{D}_{2} \mathrm{O}$ used in aluminum corrosion tests (1) turned milky (blu1sh-white) after about 60 days, probably due to colloidal $\mathrm{Al}(\mathrm{OH})_{3}$. Such dissolved corrosion products increase the conductivity of the water and increase the probability of pitting or galvanic corrosion.

Chlorlde ion concentrations as low as $7 \mathrm{ppm}$ can cause corrosion attack on aluminum. Chlorldes break down the passivity of the protective oxide layer and increase the conductivity of the water.

\section{Methods of Preventing Corrosion}

\section{High Purity Water}

High purity water with very low conductivity is an effective means of controlling the corrosion of aluminum. Tests $(4,5)$ with various ion exchange resins at the Savannah River Laboratory showed that lons are effectively removed from effluent $\mathrm{D}_{2} \mathrm{O}$ with the strong acld - strong base mixed bed resin "Amberlite" $\mathrm{XE}-150$. $\mathrm{D}_{2} \mathrm{O}$ conductivity was maintalned at $0.02 \mu \mathrm{mho} / \mathrm{cm}$, which demonstrated that the columns delonized $\mathrm{D}_{2} \mathrm{O}$ effectively and that few ionic impurities passed through the columns. Light water effluent can be reduced to a conductivity of 0.1-0.05 $\mu \mathrm{mho} / \mathrm{cm}$; bulk water conductivity can be maintained at approximately $0.1-0.2 \mu \mathrm{mho} / \mathrm{cm}$.

* Trademark of Rohm and Haas Company, Philadelphia, Pennsylvania. 
The construction and operation of an ion exchange resin column is relatively easy; minimum design requirements for a column sultable for a small research reactor are shown in Figure 1.

Continuous operation of the 1on exchange column is desirable; however, it can be used intermittently. The effectiveness and exhaustion point of the resin column are determined by the use of in-line conductivity cells with a ce.11 constant of $<0.1$.

Industrial Instruments, Inc, Cedar Grove, N. J. can supply suitable conductivity cells. Conductivity values can be read directly from a conductivity bridge (eg, Industrial Instruments Model RCl6BI) or recorded on a Brown ElectroniK Conductivity Recorder supplied by Minneapolis-Honeywell Regulator Co., Brown Instrument Division, Philadelphia, Pennsylvanla.

\section{Inhibitors}

The addition of small amounts of inhibitors to $\mathrm{H}_{2} \mathrm{O}$ or $\mathrm{D}_{2} \mathrm{O}$ effectively decreases the corrosion rate of aluminum. Tests $(6)$ have shown that chromates are specific corrosion inhibitors for aluminum in water; $\mathrm{MgCrO}_{4}$ at $0.03 \mathrm{M}$ concentration is the most effective. In addition, $0.03 \mathrm{M}$ concentrations of $\mathrm{CaCrO}_{4}$ or $\mathrm{Na}_{2} \mathrm{CrO}_{4}-\mathrm{MgCrO}_{4}$ can be used. Experience with inhibitors is limited, but no difficulty is anticipated. 


\section{BIBLIOGRAPHY}

1. Videm, K. "Pltting of Aluminum with Special Reference to P1tting of HBWR Ist Charge Fuel Elements." Report KR-8. Norway. Inst1tutt for Atomenerg1, Kjeller (196I).

2. Wilkins, N. J. M. Pltting Corrosion of Aluminum: The Significance of Cationic Equilibria in Demineralized Water. Atomic Energy Research Establishment, Harwel1, Berkshire. Report AERE M/R 1296 (1953).

3. Uhlig, H. H. "Fundamental Behavior of Galvanic Couples." Corrosion Handbook, 481-496, John Wiley \& Sons, Inc, New York (1948).

4. Baumann, E. W. Miniature Purification Progress Report, Tests Ia, Ib, and II. E. I. du Pont de Nemours \& Co., Savannah River Laboratory, Aiken, S. C. USAEC Report DP -678 (1962).

5. Baumann, E. W. Miniature Purification Progress Report II, Tests III through VI. E. I. du Pont de Nemours \& Co., Savannah River Laboratory, Alken, S. C. USAEC Report DP-806 (1962).

6. Cessna, J. C., H. M. Joseph, and R. A. Powers. "Effect of Inhibitor Cations Upon Aluminum Corrosion. I. Chromate Solutions." Corrosion 20, No. 1, 1t-6t (1964).

\section{GENERAL REFERENCES}

1. Wanklyn, J. N. and P. J. Jones. "The Aqueous Corrosion of Reactor Metals." (Atom1c Energy Research Establishment, Harwel1, Berks Eng.) J. Nucl. Mater. 6:291-329 (¿962).

2. Haynie, F. H. and S. J. Ketcham. "Electrochemical Behavior of Aluminum Alloys Susceptible to Intergranular Corrosion. II. Electrode Kinetics of Oxide-Covered Aluminum." Corrosion 19, No. 12, 403t-407t (1963).

3. Pryor, M. J. The Corrosion of Wrought Aluminum Alloys. Ka1ser Aluminum \& Chemical Corporation (1954).

4. Aziz, P. M. "Radioactive Tracers in the Study of Pitting Corrosion on Aluminum." J. Electrochem. Soc. 101, $120-123(1954)$.

5. Dunklee, A. E. The Heavy Water System of the Process Development Pile. E. I. du Pont de Nemours \& Co., Savannah River Laboratory, Aiken, S. C. USAEC Report DP -567 (1961). 